\title{
The recognition of the right of children to freedom from child labour in Africa: is it enough?
}

\author{
Emma Charlene Lubaale \\ Department of Public Law, University of Pretoria, South Africa
}

\begin{abstract}
The International Labour Organisation (ILO) envisages that by 20I6, no child should be engaged in any form of hazardous labour. This goal is a furtherance of the universally guaranteed right of all children to be protected from child labour. The majority of, if not all African states recognise the right of children to be protected from child labour. This means that this freedom cannot be taken away from children. This notwithstanding, Africa registers the highest incidence of child labour in the world and it is highly unlikely that with the current pace, the ILO target will be hit. This article argues that whereas recognising the right of children to be protected from child labour is an ideal perspective through which child labour should be viewed and addressed, such recognition cannot of itself form a complete solution to the problem. Translating this right into reality requires conscious efforts, not only on the part of African governments but the international community as a whole.
\end{abstract}

Key words: Africa, child labour, rights of children

\section{Introduction}

Globally, the number of children in child labour has declined by one third since 2000, from 246 million to I68 million (ILO, 20I3: vii). Even with this decline, more than half of the 168 million children are engaged in hazardous work (ILO, 20I3: vii). The International Labour Organisation (ILO) reports that despite the decline, "progress is still too slow and its pace needs to pick up if the world community is going to come anywhere near to meeting the 2016 goal which it aims to achieve'(ILO, 20I3: vii). The disquieting incidence of child labour in Africa makes it a cause for concern for African governments. Sub-Saharan Africa has the highest incidence of child labour in the world, to the tune of 59 million children (ILO, 2013: vii \& 4). The child labour issue is multi-faceted, often involving children struggling to make a living. Studies have rightly demonstrated that for many African children, there are powerful factors that push them into child labour (Basu \& Tzannatos, 2003: I43-I73; Admassie, 2002: 25I-276; Basu, I999: I083-III9). Indeed research findings have clearly demonstrated that child labour is influenced by a complex set of factors, often working in combination with one another. These factors render the 
exclusive reliance on restrictive measures inadequate in addressing the problem (Basu: I99: I09I \& I094). In view of the distinct circumstances under which children in Africa engage in child labour, addressing the problem through a rights based perspective has proved promising in view of its potential to take into account the various inter-related causal factors and attendant circumstances. Fortunately, many African states are signatories to a series of international human rights instruments that entrench the right of children to be free from exploitative labour. Although the broad indication is that many African governments recognise child labour as a violation of children's rights, progress in terms of combating it remains slow and piecemeal. The ILO has rightly observed that 'ending the scourge of child labour in the foreseeable future is going to require a substantial acceleration of efforts at all levels' (ILO, 2013: ix). The purpose of this article is twofold: first, to examine the limits of realisation of this right in the context of Africa and second, to discuss some of the circumstances that have to be in place in order to make this right a matter of practice rather than rhetoric. The entire discussion is geared towards arriving at the conclusion that while recognising protection of children from child labour as a right is an ideal perspective through which to view and address the problem, this cannot of itself form a complete solution to the problem. Therefore, as African governments set about addressing the problem from a rights based perspective, perhaps those governments and the international community need to concern themselves with its inherent challenges and the task that lies ahead of them. As the best examples cannot be drawn from one country, this article draws inspiration from a range of countries with a view to inform good practice.

\section{International consensus on protection against child labour as a right}

The right of children to be protected from exploitative labour has been augmented by a series of international human rights instruments (see e.g. United Nations Convention on the Rights of the Child (UNCRC), I089: art 32(I); African Charter on the Rights and Welfare of the Child (ACRWC), I990: art I5; ILO Convention, I973: art 2(I); ILO Convention, I999: art I). Many African states are party to these instruments and some states have gone a step further to entrench this right in their national constitutions and legislation. One of the utilities of recognising the protection of children from child labour as a human right is that special status is conferred on the claimed entitlement of this right. Recognition of protection of children against child labour as a right implies that it is 'designated as a condition from which children have a right to be free, not merely an option' (Weston \& Teerink, 2006: I4). Equally critical to the recognition of protection from child labour as a right is its attainment of a fundamental, universal and inalienable status. Furthermore, implicit within this right is the assurance of the right of children, as individual rights-holders to express their views freely in all issues pertaining to the alleviation of child labour and for their views to be given due consideration. ${ }^{\mathrm{I}}$ For duty

I Children's right to freedom of expression is particularly critical because children are better placed to elaborate on their conditions of work and give their account of issues that are in their vested interest. Equally, children's participation rights are critical in their claim of the full array of rights to which they are entitled. 
bearers, the stakes are raised as the struggle against child labour becomes a struggle for the best interests of children in the search for enduring solutions.

\section{Limits of realisation of the right of children to be protected from child labour in the context of Africa}

Cultural construction of childhood

Often, efforts to realise the right of children to be protected from exploitative labour underestimate the power of cultural predispositions. Recognition of children's right to protection from child labour implies that children, as human beings, are entitled to the full array of rights relevant to the realisation of this right (UNCRC, I989: preamble). Since it is envisaged that children are entitled to a full array of rights, working children are accorded a platform to influence decisions on child labour issues. Such participation is pivotal in view of the well documented fact that the best information concerning children's work conditions can most effectively be obtained from working children (Boyden \& Willian, I998: 8; UNCRC General Comment I2, 2009: para I6). In this regard, the international community has almost unanimously and repeatedly committed itself to assure the child the ability to express her views freely in all decisions affecting her (UNCRC, I989: art 7; ACRWC, I990: art 7). This commitment is critical as it demands a paradigm shift from the paternalistic approach to one where children are seen as stakeholders in decision making processes. In reality, the shift appears to create a tension between the interests of the children, families and the state. The broad indication is that states, societies and adults struggle to recognise children as partners in society who have the right to express views freely in all matters affecting them. Children continue to be viewed as incompetent, unstable, unreliable or emotional (Lowden, 2002: I00-I07; Pomerantz \& Eaton, 2000: I46-I67). As such, their views and opinions are generally disregarded; children are considered to lack the expertise and competence to inform adult decision making.

What makes the position unique in Africa is the general construction of childhood. The way children are conceptualised in a given community constitutes that society's image of childhood and as such, the rights of children recognised in that society largely depend upon the prevailing image of childhood in that community (Fionda, 200I: 8-I5). In many African societies, children continue to be seen but not heard. Unlike the western belief in absolute individual equality, the African perspective does not necessarily grant human beings equality (Rwezaura, I998: 254). Instead, each individual is positioned uniquely within the community according to social variables, age being one of the variables. There are hierarchies and within the hierarchies there are duties and obligations. Children occupy the lowest position within the hierarchy (Bell \& Aggleton, 2013: 107). Parenting style is more influenced by cultural disposition and morals are of the utmost importance. Within such settings, it is difficult to envisage a situation in which children, however alive they are to the exploitative nature of work, can make legitimate claims as envisaged. Moreover, given that part of the exploitative labour takes place within social and informal settings, it is equally hard to envisage a situation where children can stand up to the more elderly people in the name of advocating for their freedom from exploita- 
tive labour. This is in view of the fact that part of the exploitative labour is sanctioned by the adults in society, who are yet to get to grips with the exploitative nature of child labour. For many African societies, the phenomenon of exploitative labour is non-existent to adults. Work, though sometimes exploitative to children, is generally viewed from the perspective of socialisation, training, learning, character building and skills acquisition (Nieuwenhuys, 1996: 237). Although these cultural perceptions are well intentioned, some of them lead to the sanctioning and condoning of child labour. Recognising the right of children to protection from child labour, in these circumstances, can only go so far without a change in mental dispositions and belief. Similarly, in view of the general construction of childhood, recognising children as rights holders, entitled to the full array of guaranteed rights, remains a challenge without efforts to empower children.

\section{The multi-dimensional nature of the obligation to protect children from child labour}

Child labour is characterised by dangerous and exploitative work, carried out at too early an age, involving long working hours, poor working conditions, insufficient pay and involves excessive child responsibility (UNICEF, 2006: I). In view of these characteristics, it is clear that child labour is one of the forms of child abuse that impacts on multiple rights, ranging from education, health, leisure, amongst other rights. This has far-reaching implications for states as redress implies measures geared towards guaranteeing not only children's right to freedom from exploitative work, but also vouchsafing other related rights, such as the right to education, the right to health, the right to shelter, the right to freedom of expression and consciousness, the right to leisure, the right to dignity, amongst many other rights. Such a holistic approach is reinforced by the human rights principle on indivisibility and interrelatedness of human rights (Vienna Declaration, I993: 5). This principle is based on the rational assumption that each right contributes to the fulfillment of the others and that the denial of one right invariably impedes the enjoyment of other rights. From the standpoint of child labour, only when the rights addressing the root causes and consequences of child labour are realised as a whole, can children's right to freedom from exploitative work be effectively guaranteed. The multiplicity of rights involved means that multiple departments need to commit to the child labour cause. The success of realising the right of children to be protected from child labour, in these circumstances, is dependent on proper financial and administrative coordination. For many states however, this multi-departmental approach still poses considerable challenges in terms of understanding and implementation.

\section{Limited state control over certain dimensions of child labour}

Guaranteeing the right of children to be free from exploitative work is taking on new dimensions. Some of these arenas are beyond what states are conventionally accustomed to and often beyond the direct control of states. A key novel dimension in this regard pertains to child labour indirectly perpetrated and condoned by non-state actors. This era has witnessed the emergence of transnational corporations (TNCs) across many de- 
veloping countries. Most developing countries face individual TNCs with revenues many times larger than their domestic economies (Gillies, 2012: I47-I56; Rugman \& Verbeke, 2003: 3-I8). TNCs account for the top economies in the world (Greer \& Singh, 2000). Grouped together in trade associations with the active support of their home countries, TNCs exercise an inordinate influence over local laws and policies (Greer \& Singh, 2000). One way that TNCs reduce their costs and make extremely large profits is outsourcing (Antras et al., 2006: I2I; Bunyaratavej et al., 2007: 7-2I; Magnani, 2006: 617-647; Claudio \& Vivarelli, 2004: 457-482; Nayak et al., 2007: 277-284; Deavers, I997: 503-519; Taylor, I996: 394; Autor, 2006: I-42; Bartel et al., 2005). This means that factories are set up to produce those goods in developing countries where labour is cheap. Use of child labour is an often inevitable outcome as children usually require less pay. Child labour is invisibly located within the long supply chain of TNC activities. TNCs have been known to be party to children's rights violations through violations committed by its middlemen who are complicit with child labour practices.

For instance, it is documented that a number of TNCs, specialising in chocolate manufacturing, profit from cocoa procured through the use of child labour on West African cocoa farms (Griek et al., 20I0: I-Io; Mustafa, 20I0: II63-II95; Diane \& Steven, 2005). Investigations reveal that children harvest cocoa beans under conditions that qualify as the worst forms of child labour. Thousands of children in Western Africa are trafficked and forced to work on cocoa plantations (Griek et al., 20I0: 2). In a 20II study by Tulane University, it was found that I.8 million children in the Ivory Coast and Ghana work in the cocoa industry and that the vast majority of them are unpaid (Payson Center, 20II). The study also found evidence of child-trafficking, forced labour and other violations of internationally accepted labour practices. Ideally, there is a chain of production, with the impact of TNCs trickling down to children labouring within the supply chain. Notably, companies in Ghana such as the partially state-owned cocoa processing company process the cocoa beans into semi-finished products (Roldan et al., 2013: I2I-I38). ${ }^{2} \mathrm{Next}$ in the chain are grinders and chocolate manufacturers (Roldan et al., 2012). Cargill, Barry Callebaut and ADM are currently the leading grinders in the world. They buy cocoa beans from traders and process them into cocoa liquor and cocoa butter to sell to chocolate manufacturers as well as to other industries (Fold, 200I: 405-420). Chocolate companies such as Hershey, one of the leading TNCs, process the cocoa to produce a range of chocolate products (Griek et al., 20IO: I-IO). Distributors, retailers and specialised markets purchase from grinders and chocolate manufacturers, consequently distributing to consumers. TNCs' high demand for cocoa requires that cocoa farmers increase output. ${ }^{3}$ The pressure to involve child labourers alongside adult labourers, in these circumstances, becomes inevitable. Incidentally, TNCs in the later stages of the production chain are often more concerned about quantity and quality than labour standards.

2 Ghana Cocoa Board is a hybrid system. Despite all exports being controlled by the state, there are private companies buying the crop in all the areas of the country where it is grown.

3 This demand is defensible in view of the fact that, as of 2012, Ivory Coast and Ghana are thelargest producers in the world with an estimated production of 1370,000 and 675,000 tons respectively. 
In Malawi, as of 2014, it was estimated that up to $60 \%$ of the country's foreign exchange earnings are derived from tobacco production (Helema, 20I4). Malawi's children pay dearly for the world's cheap tobacco. The incidence of child labour on tobacco farms in Malawi is well documented (Liwander, 2009: $\mathrm{I}-40$ ). Child tobacco pickers in Malawi are being regularly exposed to extremely high levels of nicotine poisoning (Liwander, 2009: 33). It is reported that children are routinely abused, both physically and emotionally, to make them work harder and longer (Liwander, 2009: 38). Girls in particular are subjected to sexual abuse, often coerced by threats of withholding food, pay or employment (Liwander, 2009: 23). The children also work without proper protective clothing or equipment (Liwander, 2009: iii, 4, 20). Universal Corporation and Alliance One International are some of the TNCs that indirectly benefit from Malawi's tobacco. Their subsidiaries in Malawi, namely Limbe Leaf and Alliance One respectively, are major players in Malawi's tobacco industry (Otanez et al., 2007: 26I). Notably, Alliance One holds a leading position in most tobacco growing regions in the world, including the principal export markets for oriental tobacco in the United States, Brazil, Malawi, Turkey, Argentina, India and Thailand. In addition, it processes tobacco in more than 50 owned and third party facilities around the world. The company sells its processed tobacco primarily to large TNCs in the cigarette business, including Philip Morris International, Inc., Japan Tobacco, Inc., Imperial Tobacco Group, PLC, China National Tobacco Co., British American Tobacco, Philip Morris USA, Inc., Eastern Company S.A.E., R.J. Reynolds Tobacco Company, Lorillard Tobacco Company and others.

TNCs may argue that they neither own the cocoa farms nor control the labour practices of local farmers. Such a view is problematic and naïve in light of the long chain of production of chocolate and tobacco products. Such products only reach consumers through a chain of intermediaries which includes local farmers. An incidental suggestion may be for African governments to enforce child labour laws and for families to withdraw children from the labour market. This view, however, conveniently ignores the massive economic and power imbalance. Children do not work because they prefer working to school. They work because it is a marginally better option than starvation. Moreover, with the inordinate influence of TNCs over national laws and policies, it would similarly be naive to count on national efforts alone, to protect children from exploitative labour. The obligation of states to protect children from child labour under circumstances such as these can only go so far in guaranteeing children's entitlements.

The impact of international financial institutions has been equally significant. But as Paloni and Zanardi (2012: I) convincingly posit, '[i]n the face of the increasing importance of private sources of finance, [the prejudicial impact of loans and reliefs] from the international financial institutions goes often unnoticed.' The power and influence that these institutions wield continues to cause a serious challenge to the implementation of the right of children to be protected from exploitative labour. The World Bank and the International Monetary Fund (IMF) are two of the largest sources of international funding for development programmes. The potential of these programmes is tremendous. Much of the funding has had implications on national policies and programmes. Typi- 
cally, these loans come with conditions. The conditions for lending and debt relief set by the IMF and World Bank, often create conditions that are the opposite of those needed to protect children from child labour. In particular, policies arising from these programmes have been devastating for vulnerable populations, especially the poor. These programmes have specifically been found to have a negative impact on several fronts: devaluation of local currency, decrease in government expenditure on public services, abolition of price controls, imposition of wage controls, reduction of trade and foreign exchange controls, restrictions on domestic credit, reduction of the role of the state in the economy, increase in the basis for the export economy, decrease in imports and privatisation of public enterprises (Copelovitch, 2010: 52).

Although these policy formulations do not have a direct reference to children, their well-documented adverse impact on poverty, particularly among poor households, ultimately impacts on children. For instance, given that addressing poverty among the abject poor is documented as a major prerequisite to addressing the child labour problem, tackling the surrounding rights such as the right to education, health, housing, social security, amongst others is pivotal. However, as lending conditions often require governments to cut down on government spending, it is the sectors of education, health, social security, housing, among others, which often suffer from cuts in government expenditure. The cut in government expenditure ends up harming the welfare of the poor population. With continued poverty as a major push factor to many cases of child labour, children from chronically poor families are placed under conditions of disadvantage and strain, making them vulnerable to child labour. The need for survival leaves parents and children with few options but to condone exploitative labour activities. Further, the privatisation of state owned enterprises has not only contributed to increases in prices from privatised corporations, but also compromised the state's ability to regulate the use of child labour in private enterprises.

In a study focussing on Sierra Leone and Mozambique, Marphatia (2010: 170) demonstrates that poor health, poor education and low employment rates have been some of the ultimate outcomes of lending conditions in these two countries. As a result, the poor are increasingly forced into informal and other forms of employment associated with poor working conditions and few labour rights. A 20 Io empirical study by Harrigan and El-Said (2010: I-25) examined whether economic reforms attached to IMF and World Bank lending stimulated sustained economic growth in Egypt, Tunisia and Morocco. The study found that in all three countries, economic growth was not sustained. Rather, the successful implementation of policy reforms came at the cost of a sharp decline in public sector investment. Research by the Jubilee Debt Campaign UK found that in order to access debt cancellation under the World Bank and IMF Heavily Indebted Poor Countries (HIPC) initiative, ${ }^{4}$ Zambia had to privatise its national bank in the face of parliamentary 
and public opposition (Jubilee Debt Campaign, 2006; Zulu, 2006: I-II)). IMF policies also forced Zambia to restrict public sector spending through a wage and hiring freeze, leaving it unable to employ 9,00o desperately needed teachers. Sierra Leone has had to lay the groundwork for the privatisation of 24 state enterprises, including water, power, and telecommunications (Jubilee Debt Campaign, 2006). In Egypt, there is evidence indicating that economic liberalisation between the period of I989 and 2009 has led to the erosion of wage levels and a widening of sector pay gaps (Said, 2012: 65-IOI; Harrigan et al., 2012: 6o). An analysis of IMF and World Bank documents conducted by Jubilee Debt Campaign UK in 2006 found that of the 29 countries that completed, or were going through HIPC at the time of the study, I9 had to privatise state enterprises to obtain debt relief (Jubilee Debt Campaign, 2006: 6). As of 20I4, 36 low income countries have benefited from the HIPC initiative (IMF Debt relief fact sheet, 20I4; Cassimon, 2014). Of these, up to 27 are from the African continent and have been found eligible for HIPC (IMF Debt relief fact sheet, 20I4). In the case of Zambia, a study by the International Poverty Centre of the United Nations Development Programme found that conditions imffposed by the IMF as part of HIPC have meant less fiscal space and reduced investment in the fight against poverty after interim debt relief (Weeks \& McKinley, 2006: 7). The implication of less fiscal space is that the government's budget cannot allow the government to provide resources for a desired purpose without jeopardising the sustainability of its financial position or the stability of the economy. Weeks and McKinley point out that in Zambia, even with the expanded debt cancellation, 'regrettably, the net fiscal gain from debt relief has been marginal because of the external policy conditions linked to the relief...' (Weeks \& McKinley, 2006: 7). Rather, for decades, conditions set by external agencies will leave Zambia with little 'policy space' and very little discretion for important policy and economic decisions (Weeks \& McKinley, 2006: 7-8). Although the conditions do not necessary curtail all policy-making processes, the conditions in themselves constrain other policies not explicitly subject to conditionality. Undoubtedly, realisation of the Millennium Development Goals (MDGs) would have positively impacted on children's freedom from child labour, in view of the fact that the first two MDGs advance poverty reduction and primary education for all. However, some economic analysts have linked HIPC policies to MDG financing, demonstrating that the reduced fiscal space reduces the chances of meeting MDGs. Weeks and McKinley categorically posit that '[i]f policy conditions set by external agencies were flexible, Zambia could potentially achieve all of the MDGs, [including the poverty reduction goal], by 2015' (Weeks \& McKinley, 2006: 7-8).

Taken together, these are non-conventional actors that can hardly be penetrated by states, yet they remain a hindrance to the protection of children from child labour. Even though major human rights treaties contemplate both private and state duties, the im-

interim Poverty Reduction Strategy Paper and clear any outstanding arrears. Upon reaching deciffsion point, a country receives debt relief in the form of lower debt service payments. But no debts are actually canffcelled at decision point, and debt service relief may be suspended at any time if a country goes 'off-track' with its IMF programme. Also at decision point, the IMF and World Bank determine a final group of to to 20 conditions, called 'trigger conditions' that a country must meet in order to advance to 'completion point,' at which time the country will receive irrevocable 100\% cancellation of its eligible debt stock. 
portant nuance of holding these actors to account still provokes difficulties in understanding and implementation. The state of affairs as evident in the discussion thus far underscores the need for a number of circumstances to be in place for the right of children to be protected from child labour.

\section{Circumstances that need to be in place for the right of children to be protected from child labour to be practically realised}

Programmes in place geared towards enhancing the capabilities of uulnerable households

Amartya Sen pioneered the well known 'capabilities approach' (Sen, I985; Sen, I999; Sen, 2005: I5I-I66) which has potential to unlock new perspectives in research, decision making and the realisation of the right to protection from child labour by African governments. According to Sen, rights are not fully secured unless the related capabilities are actually present, otherwise rights are mere words on paper. In other words, the capability approach demonstrates that all human rights have social and economic conditions that require affirmative action in the form of government expenditure for their realisation. In a similar vein, Fox suggests that there is a difference between capabilities and rights. Rights may be recognised institutionally, but power imbalances often mean that actors are not able to actually claim them (Fox, 2005: 7I). Thus, a focus on capabilities as an aspect of human rights helps to emphasise the importance of the ability to exercise rights. Many writers, such as Alsop, Norton (2005: 3-I4) and Carney (2002: 37) similarly emphasise the strong conceptual affinities between rights and capabilities in their emphasis on power and respect for individuals. These writers stress that successful poverty reduction depends on providing opportunities for poor people to contest their rights through normative changes.

Critically, Sen, along with other adherents of the capability and empowerment concepts have helped build a body of empirical evidence that shows that the capabilities of individuals and groups are key public policy variables that can have a critical influence on the protection of human rights. Capability analysis also supplements traditional human rights analysis by providing an applied framework in which a range of factors that influence the realisation of human rights in practice can be more fully investigated and better understood (Vizard et al., 20II: 5). Vizard et al. (20II: I) have pointed out that 'the capability approach and human rights share a common motivation, namely 'their direct focus on the dignity and freedom of the individual.' They add that 'the capability approach can be of help in addressing some of the important controversial and unresolved issues in ethical debates about human rights' (Vizard et al., 20II: 2). They argue that the capability approach is a novel entry-point for defending the validity of a broad class of human rights concerns. Dixon and Nussbaum (2012: 554) have also justified the application of the capability approach in the context of children's rights, arguing that children are generally vulnerable as a result of their legal and economic dependence on adults. This makes their entitlements less obvious, often requiring some form of special priority in the form of capability. 


\section{Enhancing capability through measures geared towards reduction of household vulnerability to child labour}

Since poverty is a major push factor towards child labour, strengthening the capability of poor households can enable them to take initiatives to secure their own livelihoods. Poor households often lack the capacity to live independent and decent lives, and to make choices that actualise their entitlements. Accordingly, realising the right to protection from child labour will require governments and non-state actors alike to direct efforts towards enhancing capabilities of vulnerable households. Edmonds and Pavcnic (2005: 209) give four reasons why an improvement in living standards is likely to substantially ensure that children are free from child labour. First, as incomes increase, families choose to have children work less; second, the value of the marginal contribution of children's income decreases; third, higher incomes may facilitate the purchase of substitutes for child labour that may potentially lower the return to child labour within the household; and fourth, the child's productive engagement in other activities such as schooling increases, hence there is less time to engage in exploitative work.

Cash transfers for vulnerable households are some of the means of increasing capabilities and reducing household vulnerability. Cash transfer programmes are used in many countries to address the needs of poor people (Schubert \& Slater, 2006: 57I). These transfers ensure that poor households are better placed to cope with and manage the risks that come with poverty. Support can take the form of conditional transfers or unconditional transfers. Unconditional transfers target poor households and individuals with a view to increasing their incomes but with no conditions attached. These may take the form of social assistance, social pensions or family allowance programmes. For a developing country, South Africa has a commendable social welfare system. The child support grant, for instance affords support to needy primary care-givers to help them raise children in their care (South African Government Support Services: Child Support Grant, 20I4). The Child Support Grant, introduced in South Africa in I998, constitutes a rare example of a cash transfer reflecting the entitlements of poor children themselves as individuals. The fund is managed by the South African Social Security Agency (SASSA), a national agency created to administer the application, approval and payment of social grants in South Africa. Though the cash transfer is modest, amounting to 300 South African rand per month, it is a major breakthrough for many needy households. It is reported that over 15 million people in South Africa now receive cash transfers from the state (SASSA Website, 2015). The success of these transfers has been documented. In his 2004 paper, Edmonds (2004: 4) analysed the impact of the social grants on child labour and schooling decisions, and found that social grant eligibility significantly reduces child labour and increases schooling. The study found that social grant eligibility was associated with an approximately $35 \%$ decline in hours worked per week and a rise in school attendance to almost I00\%. These findings imply that because of social grant eligibility, children, who would otherwise not attend school, ultimately attend school. The author interprets this as evidence that child labour and school decisions reflect liquidity constraints rather than cost-benefit calculations, and sees an important role for social grants 
in helping households to overcome these liquidity constraints and make investments in their children's future.

Conditional transfers, on the other hand, are subject to certain terms and conditions. These may include enrolling children in schools, ensuring children's access to health care services, amongst others conditions. Typical examples of the commitment towards this nature of cash transfer are evident in Brazil, a country with one of Latin America's highest rates of child labour force participation. Brazil's successful implementation of a holistic approach to child labour is partly attributable to the use of conditional cash transfers (Rosati et al., 20II: 24-28). One such programme is the 'Programa de Erradicaçao do Trabalho Infantil (PETI programme)' (Rosati et al., 20II: 24-28; Filho, 2012: 399-435; Tabatabai, 20II: 5). The aim of the programme is to eradicate child labour by providing cash grants to families with children of school going age and by requiring children to attend school and after school activities. It is reported that in 2012, Brazil made a significant advances in its efforts to eliminate the worst forms of child labour. To eradicate extreme poverty, the government increased the budget for its social protection programme, particularly those geared towards children under the age of I5 (Brazil's worst forms of child labour report, 20I2). Over the years, studies have been conducted to analyse the impact of the programme on children's school attendance and labour market participation. A 2009 report by the World Bank shows that these programmes 'have led poor households to make more use of health and education services, a key objective for which they were designed' (Fiszbein et al., 2009: I03 \& 104). The study indicates that 'school enrolment rates have increased substantially among programme beneficiaries [and further, the probability of children engaging in child labour has been decreased].' Several other qualitative assessments demonstrate that the programme has been successful in achieving its objective of reducing rates of child labour and increasing school attendance (Soares et al., 2009: 208-2I0; Cardoso \& Souza, 2004: I-5I; Lindert, 2007: 67-74; Filho, 20I2: 399-435; Bourguignon, 2203: 229-325; ILO, 2009; Rawling \& Rubio, 2005: 29-55).

Social support impacts greatly on school attendance. Being educated is certainly a basic capability. Sen has observed that education plays a role not only in accumulating human capital but also in broadening human capability (Sen, I995: 259-273). This can be through a person benefiting from education 'in reading, communicating, arguing, in being able to choose in a more informed way, in being taken more seriously by others and so on'(Sen, I995: 259-273). Affirming the same point, Burchi (2008: 20) observes that 'the capability approach entails social benefits that education produces which entail the ability to communicate, to be taken seriously by others and to take conscious decisions'. This means that children and society are equipped with valued choices, consequently, being capable of making informed decisions on issues pertaining to child labour. Since Sen's capability approach is based on the capability of participants to choose a life they themselves have reason to value, the approach instils a sense of community ownership of the redress process. Ideally, the state does not directly involve itself in the withdrawing of children from the labour market. Rather, parents and children are equipped with the means to exercise child-sensitive choices, making it easier for programmes to combat child labour to be implemented. 
Taken together, realising the right of children to be protected from child labour faces African governments with the challenge of enhancing the capabilities of vulnerable households. Indeed, such broad interventions have far reaching financial implications. However, the African Commission on Human and Peoples' Rights accurately qualified the resource limitation, noting, among others, that despite the resource constraints, African governments should take 'concrete and targeted steps, while taking full advantage of its available resources, to ensure [that social economic rights are realised]' (Purohit v The Gambia, 2003: para 84). Equally, the Committee on Economic, Social and Cultural Rights (CESCR) has elaborated on the nature of states' obligation, with respect to the minimum core obligation in the progressive realisation of socio-economic rights. In light of article 2 of the International Covenant on Economic, Social and Cultural Rights (ICESCR), which refers to the progressive realisation of the rights, depending on the available resources, the CESCR has given an interpretative guideline that where a state cannot meet the full realisation of a right due to a lack of resources it must at least endeavour to meet a certain minimum level content of the right (CESCR General Comment 3, I990). Moreover, the state must demonstrate that it has deployed its available resources to the maximum extent with a view to at least satisfying, as a matter of priority, the minimum obligation.

\section{Integrated multi-sector approaches cognisant of the multi-faceted nature of child labour}

As child labour issues are cross cutting within the multiple departments, mainstreaming multi-sectorality is a key pillar of any effort geared towards translating the right of children to protection from child labour into reality. Integration should be both vertical and horizontal. Vertical integrated multi-sector efforts should ensure that child labour interventions are mainstreamed into the routine schedules of the mandated sectors. In this regard, it will be incumbent on the individual sectors to make the child labour agenda a golden thread that runs through all programmes. Horizontal integrated multi-sector efforts on the other hand should strive to ensure that there is coordination and links among various players and sectors involved. States will need to coherently coordinate the mandates of the various departments, finances, polices, laws and programmes. This implies improved and stronger interaction between various departments and ministries including the ministry of social affairs, the family, health, education, justice, labour, finance, among others. One pertinent issue is whether coordination among the various sectors concerned is really alien to many African governments. From a more novel perspective, an integrated and more coordinated approach should be generally seen as a conscious organisation design, reorganisation and coordination among concerned sectors. This entails creation of networks among government departments, NonGovernment Organisations (NGOs) and local communities on programmes and services directed at addressing the problem. A more coordinated approach among concerned sectors should be able to usher in some form of interconnectedness in policies and programmes geared towards realising this right. 
Brazil presents a noteworthy example of appropriate coordination in the realisation of the right to freedom from child labour. Coordination between different government entities was improved within the context of an initiative to strengthen the labour inspections services (ILO \& FAO, 20II: 49). Using a coordinated team of 'intelligence' action-labour inspectors, cases of child labour were discovered and addressed. Action was equally taken against the precarious working conditions prevailing on some vessels. One of the isolated child labour programmes in Brazil that presents a typical example of the critical role of multi-sector coordination is one conducted in the fisheries sector of the state of Rio de Janeiro. During labour inspection operations in this state in 2010, a coordinated operation involved the National Coordination of Port and Waterway Labour Inspection (CONITPA) in collaboration with the Navy, the Federal Police, the Ministry of Labour and Employment, the Ministry of Fisheries and the Ministry of the Environment. During this operation, children were found working as divers untangling nets from motor propellers (ILO \& FAO, 20II: 49). These children were referred to the care of the social services and their employers fined. It is evident that it took more than one sector of government to deliver these children from exploitative work. Re-affirming the critical role of coordination among various sectors, as part of the implementation of the second plan to combat human trafficking in 2012, the Government of Brazil expanded the number of inter-agency coordination centers on child labour, from Io to I6 (Brazil findings on the worst forms of child labour, 2012). In the same year, the State of Rio de Janeiro established a committee to combat trafficking in persons that includes 29 state government agencies. Similarly, in Ghana, there is a 'National Plan of Action' in place (Ghana Child Labour Monitoring, 2010: 9). It is an integrated framework that seeks to bring together the various sector-oriented activities under a multi-faceted design to address the issue in a more coordinated and sustainable fashion. The framework aims at achieving important national and international goals, including the Millennium Development Goals, Education for All by 2015, and the Child Labour targets in the ILO Decent Work Agenda for Africa for the period between 2007 and 2015.

\section{Programmes cognisant of local communities as valuable partners}

Freeman (I984) propounded a theory known as the 'stakeholder theory.' Freeman's theory offers perspectives on the critical need to recognise the role of stakeholders in the realisation of the right of children to protection from child labour. Freeman notes that each stakeholder has a right to be treated as a means to some end and therefore must participate in determining the future direction. For Freeman, stakeholders are the relevant parties since they will be materially affected by the outcome. The stakeholder theory, in other words, demonstrates that better decision making is promoted when the views of the main actors concerned about a particular decision are heard and integrated at all stages through dialogue and consensus building. The process takes the view that everyone affected by the process has a valid view and relevant knowledge and experience to bring to the decision making process. 
Critically, Freeman has helped to build up a body of empirical evidence that establishes the role of fully involving all stakeholders in implementing solutions to common problems or goals. The theory has the potential to foster transparency and inclusive decision making as it increases opportunities for effective participation by those most directly effected by decisions, particularly those at the grassroots level who are often voiceless. The process can equally enhance democracy as it ensures that decisions made reflect and respond to local concerns. Because the processes are flexible, responsive and able to adjust to changing contexts, the processes can reconcile different interests, reach consensus solutions and allow for trust building.

A considerable number of children engage in exploitative work within the context of communities where they are situated. This makes programmes that recognise local communities as valuable partners critical to the realisation of the right of children to be free from exploitative labour. It has long been argued that guaranteeing the rights of children may be partly dependent on adults who exercise care giving roles over them. In view of the dominion that parents and adults within local communities wield over children, adults can act as gatekeepers, influencing whether or not children are protected. Hence, the right of children to be protected from exploitative labour is more likely to be guaranteed if programmes geared towards this cause are inclusive, acceptable and owned by local communities where child labour is predominantly situated. Parents and adults within these communities should therefore be seen as partners in the shared responsibility of addressing child labour. An approach, based on trust, respect and acknowledgement of the diversity in cultures, presupposes stronger partnerships between children, families and the state. It equally shows potential in terms of surmounting the seemingly impenetrable cultural attitudes on childhood and work. There may be resistance to abiding by programmes 'from above', particularly in remote areas. However, with an approach that furthers shared responsibility, local communities are elevated to a level of partners, creating a sense of ownership and active participation in projects geared towards combating child labour.

Community based initiatives, with close community participation, have proved to be effective in a noteworthy programme in Ghana. The programme concerned child labourers on Lake Volta (International Organisation of Migration, 20I3: I-3; Fawcett, 2013). Between 2002 and 2013, the International Organization for Migration (IOM) withdrew close to 700 children from child labour in the fisheries sector on the Lake. The children that were released from child labour were taken to government rehabilitation centres and given counselling, medical assistance, educational assistance and art therapy for three and a half months. Project activities also included visits to fishing villages by IOM and its local partners for awareness raising. Perhaps more impressive, is the fact that IOM engaged with the chiefs, parents and other community members throughout the implementation of the programme. Parents were assisted in identifying income-generating opportunities to address issues of vulnerability. Parents who released their children also received training and were provided with micro credits to enable them to carry out alternative livelihood activities and improve their fishing techniques without using child 
labour. Thus, parents and the general community should play an active role in proposed projects. In effect, these projects will not be seen as an outside intervention but more as an organic collaboration that remains close to community concerns and priorities. This is not only crucial to the sustainability of project goals, but also, can sooth the tension between local communities and the state, and increasingly opening the door to recognition of children as rights holders.

\section{Third party states, 'parent companies' and international agencies keen on proactively influencing arenas beyond the reach of affected African states}

With the inordinate influence that TNCs have over national laws and policies, holding these companies to account is an uphill task (Otanez et al., 2007: 26I-I69). However, since TNCs are merely situated in selected countries but with headquarters in specific countries, it can be argued that the states where the headquarters are situated have obligations as it pertains to activities and operations of TNCs. Imposing an obligation on these states may be quite problematic since as Donaldson (I996: 56) so rightly puts it, '[in these cases, there is always] a moral space, a grey zone [in which] there is no tight prescription [for a company's behaviour].' However, this obligation seems to have implicitly attained a level of international consensus. The Maastricht Guidelines point out that ' $[t]$ he obligation to protect includes the state's responsibility to ensure that private entities or individuals, including transnational corporations over which they exercise jurisdiction, do not deprive individuals of their economic, social and cultural rights. States are responsible for violations of economic, social and cultural rights that result from their failure to exercise due diligence in controlling the behaviour of such non-State actors' (Maastrich Guidelines, I997: paras I8 \& I9). The Guidelines further underscore the critical importance of the idea that states 'use their influence' to ensure that policies and programmes are sensitive to human rights. Obligations relating to international cooperation are further bolstered by several other international instruments. The United Nations Charter calls on members to take 'joint and separate action' to promote higher standards of living, full employment, and conditions of economic and social progress and development, solutions of international economic, social, health, and related problems and universal respect for, and observance of human rights (Charter of the United Nations, 1945: arts $55 \& 56$ ). A similar obligation is re-echoed by the ICESCR (I976: art I).

In terms of the child labour conundrum in West Africa, particularly Ghana, Barry Callebaut Limited, has a branch in Ghana, but has its headquarters in Switzerland (Barry Callebaut website, 20I4). Cadbury-Kraft Foods Ghana Limited is a subsidiary of Cadbury, a United Kingdom based TNC (Kraft foods group website: 20I4). ADM Cocoa (Ghana) Limited, one of the largest chocolate manufacturers has headquarters in the USA (ADM website, 20I4). Cargill Ghana Limited is a subsidiary of Cargill, a TNC with headquarters in the USA (Cargill website, 20I4). It is reported that Ghana's cocoa sector produces approximately $20 \%$ of the world's crop and it is Cargill's second-largest producing country. In Malawi, Universal Corporation and Alliance One International have headquarters in Switzerland and USA respectively (Otanez et al., 2007: 26I). A study conducted by Ferner 
(I997: 33) has affirmed that countries where headquarters of TNCs are based can influence the operations of TNCs internationally. The study found that the management of human resource at the headquarters can significantly impact on cross national management of personnel and human resource issues. The characteristics of human resource management at the headquarters are likely to influence the way in which TNCs manage human resource internationally. Greer and Singh (2000) similarly demonstrate that 'parent' companies at the headquarters can exercise authoritative controlling influence over 'subsidiary' companies in other countries, either directly, if a private company, and if it is public, by owning shares. From the stand point of child labour, states and 'parent companies' should proactively and collectively influence the functioning of TNCs by penetrating arenas beyond the influence of affected states.

Despite the tendency for TNCs to be aloof about their role in adhering to labour standards, such an attitude has in a few exceptional circumstances been brought to the public eye. In 2012, Hershey Company, a leading TNC in the cocoa production chain was sued by the Louisiana Municipal Police Employees Retirement System (Reuters, 2012). The retirement system, a Hershey shareholder sought documents which could determine if the candy maker knew its suppliers in Ghana and Ivory Coast used child labour. The retirement system noted with concern that '[b]y producing chocolate at its Pennsylvania factory that is the product of child and forced labour in West Africa, Hershey has flouted domestic and foreign law and placed at risk its century old brand and reputation' (Reuters, 2012). But Hershey denied requests for transparency arguing that it does not purchase cocoa beans directly from West African farms and instead buys processed ingredients from TNCs (Hsu, 20I2). On I8 March 20I4, the Delaware Chancery Court Judge, Travis Laster, ruled that the shareholders' request to see cocoa-supply chain records should be allowed (Feeley, 20I4). The reasoning of the learned judge creates a reasonable possibility of calling TNCs to greater account for child labour practices within the supply chain.

As it pertains to international financial institutions such as the World Bank and IMF, their duties and responsibilities should correspond with their direct and indirect influence upon child labour. The conditions to lending notwithstanding, within the context of protecting children from child labour, donors and states alike should give primary consideration to the best interests of children by regulating expenditures to counter the adverse effects of these policies on children. Conceivably, where expenditures on basic necessities are regulated, child labour as a supplement to household income is minimised. International financial institutions should take a leading role in this regard because individual states seem handicapped where donations and debt relief are subject to stringent conditions. It is advisable that even with conditions in place African governments should be afforded wider fiscal space to provide resources for the desired purpose of furthering the right of children to be protected from child labour.

Further, debt relief and lending terms should take into account the unique situation of each individual country. The relief offered to each individual country should be aligned to national development plans and priorities within the context of the country's budgets 
so that states are not deterred from expenditure in priority sectors. Fallon \& Tzannatos recommend that in addition to ensuring that donor financed projects do not contribute to the problem, international donors' operational practices should ensure that in countries with a serious risk of child labour, there are appropriate safeguards in the lending agreements (Fallon \& Tzannatos, I998: 13-22).

\section{Conclusion}

The right of children to be protected from child labour has unanimously been endorsed by all African governments, a commendable starting point. If, as envisaged by the ILO, the worst forms of child labour are to be eradicated by 2016 , then it appears African governments need to do more than recognise child labour as a violation of children's rights. African governments need get to grips with the challenges of realising this right. Consequently, African governments should develop new techniques to translate this right into reality. Realising this right assumes increased recognition of local communities as valuable partners and increased coordination across government departments, non-government organisations and local communities. The onus is ultimately on the states to substantially enhance the capability of vulnerable households. Nevertheless, African governments cannot succeed on their own. The influence and economic assistance of the industrialised world and international agencies is essential.

\section{References}

Abraham, Katherine \& Taylor, Susan (1996). Firms' use of outside contractors: Theory and evidence. Journal of Labour Economics, I4: 394-424.

Admassie, Assefa (2002). Explaining the high incidence of child labour in Africa. African Development Bank, I4: $25 \mathrm{I}-276$.

Antras, Pol, Garicano, Luis \& Rossi-Hansberg, Esteban (2006). Offshoring in a knowledge economy. Quarterly Journal of Economics, I2I:3I-77.

Alsop, Ruth \& Norton, Andrew (2005). Power, rights and poverty reduction. In Alsop, Ruth (ed.), Power, rights and poverty: concepts and connections, 3-I4. Washington: World Bank.

Autor, David (2006). Outsourcing at will: The contribution of unjust dismissal doctrine to the growth of employment outsourcing. Journal of Labour Economics, 2I: I-42.

Barrientos, Armando \& DeJong, Jocelyn (2006). Reducing Child Poverty with Cash Transfers: A Sure Thing? Development Policy Review, 24: 537-552.

Basu, Kaushik (1999). Child labour: Cause, consequence, and cure, with remarks on international labour standards. Journal of Economic Literature, 37: 1083-III9.

Basu, Kaushik \& Tzannatos, Zafiris (2003). The global child labour problem: What do we know and what can we do? The World Bank Economic Review, 17: I47-173.

Bell, Stephen \& Aggleton, Peter (2013). Social influences on young people's sexual health in Uganda. Health Education, II3: I02-II4.

Bourguignon, François, Ferreira, Francisco \& Leite, Phillippe (2003). Conditional cash transfers, schooling and child labour: Micro-simulating Bolsa Escola. The World Bank Economic Review, 17: 229-254.

Boyden, Jo \& William, Myers (1998). Child labour: The best interest of working children. London: Save the Children, I-30.

Bunyaratavej, Kraiwinee, Hahn, Eugene \& Doh, Jonathan (2007). International off shoring of services: A parity study. Journal of International Management, 13: 7-21. 
Burchi, Francesco (2008). On the relationships among education, development and food security through the capability approach. Rome: PhD Thesis, Roma Tre University, Department of Economics.

Cardoso, Eliana \& Souza, André (2004). The impact of cash transfers on child labour and school attendance in Brazil. Working Paper, 4: I-5I.

Carney, Diana (2002). Sustainable Livelihood Approaches: Progress and Possibilities for Change. Toronto: Department for International Development, I-67.

Case, Anne, Hosegood, Victoria \& Lund, Frances (2005). The reach and impact of Child Support Grants: Evidence from KwaZulu-Natal. Development Southern Africa, 22: 467-482.

Cassimon, Danny (2014). Africa: Out of debt, into fiscal space? Dynamic fiscal impact of the debt relief initiatives on African Heavily Indebted Poor Countries (HIPCS). Unpublished.

Claudio, Piga \& Vivarelli, Marco (2004). Internal and external R\&D: A sample selection approach. Oxford Bulletin of Economics and Statistics, 66: 457-482.

Copelovitch, Mark (2010). Master or servant? Common agency and the political economy of IMF lending. International Studies Quarterly, 54: 49-77.

Deavers, Kenneth (I997). Outsourcing: A corporate competitiveness strategy, not a search for low wages. Journal of Labour Research, I8: 503-519.

Diane, Mull \& Steven, Kirkhorn (2005). Child Labour in Ghana cocoa production: Focus upon agricultural tasks, ergonomic exposures, and associated injuries and illnesses. Public Health Rep, I20: 649-656.

Dixon, Rosalind \& Nussbaum, Martha (2012). Children's rights and a capabilities approach: The question of special priority. Cornell law Review, 97: 549-599.

Donaldson, Thomas (1996). Values in tension: Ethics away from home. Harvard Business Review, 74: 48-64.

Edmonds, Eric (2004). Does illiquidity alter child labour and schooling decisions? Evidence from household responses to anticipated cash transfers in South Africa. National Bureau of Economic Research, I-5I.

Edmonds, Eric \& Pavcnik, Nina (2005). Child Labour in the Global Economy. The Journal of Economic Perspectives, 19: 199-220.

Edmonds, Eric (2006). Child labour and schooling responses to anticipated income in South Africa. Journal of Development Economics, 8r: 386-4I4.

Fallon, Peter \& Tzannatos, Zafiris (1998). Child labour issues and directions for the World Bank. Washington: World Bank, I-22.

Ferner, Anthony (1997). Country of origin effects and human resource management in multinational companies. Human Resource Management Journal, 7: 19-37.

Filho, Carvalho (2012). Household income as a determinant of child labour and school enrolment in Brazil: Evidence from a social security reform. Economic Development \& Cultural Change, 60: 399-435.

Fionda, Julia (200I). Legal Concepts of childhood: An introduction. In Fionda, Julia (ed.), Legal concepts of Childhood. 3-17. Portland: Hart Publishing.

Fiszbein, Ariel \& Schady, Norbert (2009). World Bank Policy Research Report on Conditional cash transfers. Washington: World Bank, I-36r.

Fold, Niels (200I). Restructuring of the European chocolate industry and its impact on cocoa production in West Africa. Journal of Economics Geography, I: 405-420.

Fox, Jonathan (2005). Empowerment and institutional change: Mapping virtuous circles of state-society interaction. In Alsop, Ruth (ed.), Power, rights and poverty: Concepts and connections. 68-92. Washington: World Bank.

Freeman, Edward (1984). Strategic management: A stakeholder approach. Boston: Pitman, I-292.

Gillies, Grazier (2012). Transnational corporations and international production: Concepts, theories and effects. London: Edward Elgar, I-240.

Greer, Jed \& Singh, Kavaljit (2000). A brief history of transnational corporations. Unpublished.

Griek, Lotte, Penikett, Jennifer \& Hougee, Esther (2010). Bitter harvest: Child labour in the cocoa supply chain. Sustainalytics, I-IO. 
Harrigan, Jane \& El-Said, Hamed (2010). The Economic Impact of IMF and World Bank Programmes in the Middle East and North Africa: A Case Study of Jordan, Egypt, Morocco and Tunisia. 1983-2004. Review of Middle East Economics and Finance, 6: I-25.

International Organisation of Migration (IOM) Ghana (2013). Counter trafficking update-Child trafficking child protection campaign, Free to be me. Ghana: International Organisation of Migration, I-3.

Jubilee Debt Campaign (UK) (2006). Cut the strings: Why the UK government must take action now on the harmful conditions attached to debt cancellation. London: Grayson Center, I-24.

Lindert, Kathy (2007). Brazil: Bolsa Familia Programme-Scaling-up cash transfers for the poor. MfDR Principles in Action: Sourcebook on Emerging Good Practices, 67-74.

Liwander, Anna (2009). Child labour in tobacco production: Children's experiences and tobacco companies corporate social responsibility initiatives. I-44. Unpublished.

Lowden, Jacqueline (2002). Children's rights: A decade of dispute. Journal of Advanced Nursing, 37: 100-107.

Magnani, Elisabetta (2006). Technological diffusion, the diffusion of skill and the growth of outsourcing in US manufacturing. Economics of Innovation \& New Technology, 15: 617-647.

Marphatia, Akanksha (2010). The adverse effects of International Monetary Fund programmes on the health and education workforce. International Journal of Health Services, 40: 165-178.

Ministry of employment and social welfare (2010). Ghana child labour monitoring system. Ghana: Ministry of employment and social welfare, $\mathrm{I}-56$.

Mustapha, Kemi (2010). Taste of child labour not so sweet: A critique of regulatory approaches to combating child labour abuses by the US chocolate industry. Washington University Law Review, 87: II63-II95.

Nayak, Kumar, Sinha, Jogendra \& Guin, Kalyan (2007). The determinants and impact of outsourcing on small and medium enterprises-An empirical study. IIMB Management Review, I9: 277-284.

Nieuwenhuys, Olga (1996). The paradox of child labour and anthropology. Annual Review Anthropology, 25: 237-25I.

Oberdabernig, Dorris (2013). Revisiting the effects of IMF programmes on poverty and inequality. World Development, 46: II3-I42.

Otanez, M.G., Mamudu, S \& Glantz, S.A. (2007). Global leaf companies control the tobacco market in Malawi. Tob Control, I6: 26I-269.

Paloni, Alberto \& Zanardi, Maurizio (2012). The IMF, World Bank and policy reform: Introduction and overview. In Paloni, ALberto \& Zanardi, Maurizio (eds.), The IMF, World Bank and policy reform. pp. I-I25. New York \& London: Routledge.

Payson Center for International Development (20II). Tulane cocoa child labour. Unpublished.

Pomerantz, Eva \& Eaton, Missa (2000). Developmental differences in children's conceptions of parental control: They love me, but they make me feel incompetent. Merrill-Palmer Quarterly, 46: I40-I67.

Purohit v The Gambia (2003). AHRLR 96 (ACHPR 2003).

Rawlings, Laura \& Rubio, Gloria (2005). Evaluating the impact of conditional cash transfer programmes. The World Bank Research Observer, 20: 29-55.

Roldan, Maria, Fromm, Ingrid \& Aidoo, Robert (2013). From production to export markets: The case of the cocoa value chain in Ghana. Journal of African Development, I5: I2I-I38.

Rosati, Furio, Manacorda, Marco, Kovrova, Irina, Koseleci, Nihan \& Lyon, Scott (20II). Understanding the Brazilian success in reducing child labour: Empirical evidence and policy lessons. Italy: International Labour Organisation, I-88.

Rugman, Allan \& Verbeke, Alain (2004). A perspective on regional and global strategies of multinational enterprise. Journal of International Business Studies, 35: 3-18.

Rwezaura, Bart (1998). Competing images of childhood in the social and legal systems of contemporary Sub Saharan Africa. International Journal of Law, Polity \& the Family, I2: 253-278.

Said, Mona (2012). Wage differentials during economic reform and crisis: Evidence from Egypt and Jordan. Comparative Economic Studies, 54: 65-ror. 
Schubert, Bernd \& Slater, Rachel (2006). Social cash transfers in low-income African countries: Conditional or unconditional? Development Policy Review, 24: 57I-578.

Sen, Amartya (1985). Commodities and Capabilities. Amsterdam: Oxford University Press, I-IO2.

(I995). Gender, inequality and theories of justice. In Nussbaum, Martha \& Glover, Jonathan (eds.), Women, Culture and Development: A Study of Human Capabilities. 259-273. Oxford: Clarendon Press.

_ (1999). Development as Freedom. New York: Oxford University Press, I-384. (2005). Human rights and capabilities. Journal of Human Development, 6: I5I-I66.

Soares, Sergei, Osório, Rafael, Soares, Fábio, Medeiros, Marcelo \& Zepeda, Eduardo (2009). Conditional cash transfers in Brazil, Chile and Mexico: Impacts upon inequality. Estudios Economicos, 207-224.

Tabatabai, Hamid (2010). Conditional cash transfers and child labour: Experiences and opportunities. Geneva: International labour Organisation, I-I4.

Triegaardt, Jean (2005). The Child Support Grant in South Africa: A social policy for poverty alleviation? International Journal of Social Welfare, I4: 249-255.

Vizard, Polly, Fukuda-Parr Sakiko \& Elson, Diane (20II). Introduction: The Capability approach and human rights. Journals of Human Development and Capabilities, I2: I-22.

Weston, Burns \& Teerink, Mark (2006). Child labour through a human rights glass brightly. Unpublished.

World Vision (2012). Our guilty pleasure: Exploitative child labour in the chocolate industry. Australia: World Vision.

Zulu, Jach. (2006). Zambia after the HIPC surgery and the completion point. Lusaka: Jesuit Center for Theological Reflection, I-II.

\section{International instruments and documents}

African Charter on the Rights and Welfare of the Child, I990.

Charter of the United Nations, 1945.

Committee on Economic Social and Cultural Rights (CESCR) General Comment 3 of rg9o,

UN.DOC.E/I99I/23. Committee on the Rights of the Child, through its General Comment I2

UN.DOC.CRC/C/GC/12 of 2009 on children's right to be heard.

ILO Convention No 138, Minimum Age Convention, 1973.

ILO (2013). Marking progress against child labour: Global estimates and trends 2000-2012. Geneva: International Labour Organisation, $\mathrm{I}-48$.

ILO \& FAO report (20II). Good practice guide for addressing child labour in fisheries and aquaculture: Policy and practice. FAO \& ILO, I-75.

International Covenant on Economic Social and Cultural Rights, 1976. Maastricht Guidelines on Violations of Economic, Social and Cultural Rights, 1997.

United Nations Convention on the Rights of the Child, r989.

United Nations Children's Fund (2006). Child Protection Information Sheet. New York: UNICEF, I-I8.

Vienna Declaration and Programme of Action by the world conference on human rights (25 June 1993) UN DOC.A/A/CONF.157/23.

Worst Forms of Child Labour Convention No I82, 1999.

\section{Websites}

ADM website. www.adm.com(accessed 7 September 2014).

Alliance One Tobacco (Malawi) Ltd website.

http://www.ide.go.jp/English/Data/Africa_file/Company/malawio2.html (accessed 28 August 2014).

Barry Callebaut website. www.barry-callebaut.com(accessed 7 September 20I4). 
Brazil 2012 findings on the worst forms of child labour.

http://www.dol.gov/ilab/reports/child-labor/brazil.htm (accessed 25 August 20I4).

Cargill website. www.cargill.com (accessed 7 September 2014).

Factsheet on Debt Relief Under the Heavily Indebted Poor Countries (HIPC) Initiative https://www.imf.org/external/np/exr/facts/hipc.htm (accessed I September 20I4).

Fawcett, Sharon (2013). Child labour and enslavement in Ghana's Lake Volta fishing industry. Unpublished. http://stopchildlabor.org/?p=3554 (accessed 20 August 2014).

Feeley, Jef (2014). Hershey investors suing over child labour can pursue files.

http://www.bloomberg.com/news/2014-03-18/hershey-judge-says-shareholders-can-seek-child-laborfiles-I-.html(accessed 3 September 20I4).

Helema. Tobacco revenue hits \$269.9 million.

http://mwnation.com/tobacco-revenue-hits-269-9-million/ (accessed 5 September 2014).

Hershey sued for info on use of child labour in cocoa supplies. http://www.reuters.com/article/20I2/II/OI/ hershey-childlabor-idUSLIE8MiGSB20I2IIOI(accessed 3 September 2014).

Hsu, Tiffany (2012). Hershey sued over African cocoa farm child labour accusations. http://articles.latimes.com/20I2/nov/02/business/la-fi-mo-hershey-cocoa-child-labor-20I2IIO2 (accessed 3 September 20I4).

Kraft foods group website. www.kraftfoodsgroup.com/ (accessed 7 September 20I4). 